\title{
Katarzyna Orszulak-Dudkowska
}

Zakład Etnologii i Folklorystyki

Instytut Etnologii i Antropologii Kulturowej

Wydział Filozoficzno-Historyczny

Uniwersytet Łódzki

\section{Lódź, moje miasto... Obraz Lodzi w opiniach lódzkich studentów}

Związek człowieka z określonym terytorium od dawna lokowany był u podstaw rozważań dotyczących problematyki rozmaitych grup społecznych. W tradycji etnograficznej zaś specyfika zajmowanego przez grupę obszaru przestrzennego stanowiła jeden z podstawowych elementów służących budowaniu ogólnego obrazu grupy, tworzonego przez badacza na zasadzie zewnętrznego oglądu. Terytorium zajmowane przez grupę, wraz ze swą społeczno-kulturową specyfiką, nie straciło również swej ważności w perspektywie prowadzonych przez etnologów badań, dotyczących kwestii grupowej świadomości i poczucia wspólnej tożsamości. Relacje łączące ludzi z doświadczanym na co dzień terenem wciąż stanowią bardzo ważny czynnik przekładający się na tworzenie grupowej więzi, poczucie identyfikacji z określonym środowiskiem społecznym i jego historią, wpływając także na jego aktualne potrzeby oraz dążenia dotyczące przyszłości.

W naukach społecznych stosunek człowieka do określonej przestrzeni stał się również punktem wyjścia dla rozmaitych ustaleń teoretycznych. Stanisław Ossowski jako znany badacz relacji pomiędzy człowiekiem a terytorium wprowadził rozróżnienie na ojczyznę prywatną i ojczyznę ideologicznąa ${ }^{1}$ które okazało się ważną inspiracją dla badań problematyki lokalności, kontynuowanych i rozwijanych przez wielu innych autorów. Wprowadzone przez S. Ossowskiego pojęcie ojczyzny prywatnej odnoszone jest zwykle do subiektywnego, osobistego i głęboko emocjonalnego doświadczania terenu o charakterze lokalnym. W kulturowe wyobrażenie tej indywidualnie postrzeganej i odczuwanej przestrzeni wpisują się bezpośrednio zapoznane miejsca, szlaki, obiekty architektury i krajobrazy oraz konkretni ludzie. Jest to przestrzeń nasączona osobistymi wspomnieniami, sentymentem i emocjami oraz własną, zazwyczaj rodzinną codziennością. Zdaniem S. Ossowskiego ojczyzna prywatna to także kulturowy obszar, wobec którego człowiek posiada pewien moralny obowiązek; jest z nim połączony

${ }^{1}$ S. Ossowski, Analiza socjologiczna pojęcia ojczyzny, [w:] idem, Dzieła, t. 3, Z zagadnień psychologii spotecznej, Warszawa 1967, s. 201-226. 
więzią o charakterze losowym i nieodwracalnym. A zatem wobec tak rozumianej przestrzeni człowiek nie może pozostawać po prostu obojętny. Tak przedstawia się nieco zmityzowany obraz ojczyzny prywatnej, wykorzystywany powszechnie w tekstach poetyckich i prozatorskich jako uosobienie świata idealnego, ale zwykle utraconego, związanego z głęboko emocjonalnym doświadczeniem rzeczywistości i wywoływaniem poczucia nostalgii.

Ojczyzna prywatna w rozważaniach wielu innych autorów określana jest także mianem tak zwanej małej ojczyzny. Antropologiczna figura małej ojczyzny stanowi kontynuację rozważań S. Ossowskiego, ale badacze przywołują także jej nieco inne, odbiegające od pierwowzoru, społeczno-kulturowe konotacje. Odwołania do wyobrażenia małej ojczyzny w sferze pragmatyki kulturowej stanowić mogą także sposób na rekonstrukcję czy też budowanie od podstaw lokalnej, zazwyczaj regionalnej lub miejskiej tożsamości ${ }^{2}$. Mała ojczyzna pojawia się wówczas jako hasło propagujące idee wspólnego myślenia o zajmowanej przestrzeni oraz podejmowania rozmaitych obywatelskich działań na rzecz wspólnego lokalnego dobra. Spotykana jest również jako stereotypowe sformułowanie przywoływane w kontekście kampanii reklamowych i politycznych, służące doskonale składaniu różnego rodzaju obietnic dotyczących potencjalnej przyszłości lokalnego świata. Współczesny powrót do lokalności, ponowne odkrywanie i kreowanie własnych miejsc to także intelektualna i organizacyjna reakcja na procesy koncentracji, centralizacji i standaryzacji zachodzące w zglobalizowanym świecie. Wciąż zatem potwierdza się pewna społeczna reguła, mówiąca, że: „Rodzinna wieś, miasteczko czy miasto, istniejące tu i teraz, są zazwyczaj ludziom bliższe niż nieskonkretyzowany, nieczytelny i obcy w istocie świat czy kontynent"3. Nie oznacza to lekceważenia sprawczej roli wielkich społeczeństw kontynentalnych, ale służy raczej dowartościowaniu lokalnego świata, który dla wielu ludzi w sposób całkiem naturalny wciąż pozostaje rzeczywistością podstawową, w której skupiają się rozmaite aktywności z zakresu życia codziennego.

Mając na uwadze wielowarstwowe znaczenia pojęcia małej ojczyzny, postaram się wykorzystać je w analizie zebranych wyników badań etnograficznych, dotyczących poczucia osobistych związków ludzi z przestrzenią miasta na przykładzie Łodzi.

Badania przeprowadzono przy współudziale studentów II roku etnologii Uniwersytetu Łódzkiego (rok akademicki 2011/2012), którzy pracowali nad realizacją projektu pod moim kierunkiem. Szczegółowym badaniem objęta została grupa 75 studentów wybranych łódzkich uczelni wyższych - Uniwersytetu Łódzkiego (UŁ), Politechniki Łódzkiej (PŁ), Uniwersytetu Medycznego (UM),

${ }^{2}$ Zob. Cz. Robotycki, Historia - folklor - tradycja a kwestia małej ojczyzny, [w:] idem, Nie wszystko jest oczywiste, Kraków 1998, s. 47.

3 B. Jałowiecki, M. S. Szczepański, Miasto i przestrzeń $w$ perspektywie socjologicznej, Warszawa 2006, s. 331. 
Akademii Sztuk Pięknych (ASP) i Społecznej Akademii Nauk4. Wszystkie rozmowy prowadzone były w okresie od grudnia 2011 do lutego 2012 r., za pomocą techniki wywiadu swobodnego ${ }^{5}$. Grupa badaczy zaangażowanych w projekt posługiwała się zestawem dyspozycji do wywiadów, które wyznaczały kierunek prowadzonych rozmów. Same wywiady w praktyce miały jednak charakter otwarty i nieustrukturyzowany; przybierały formę swobodnie prowadzonych rozmów i nawarstwiających się w ich trakcie dygresji, otwierających częstokroć nowe ścieżki analizy tematu, których zespół badawczy nie zakładał we wstępnej fazie projektu. Przyjęta technika zbierania materiałów pozwalała rozmówcom na bieżąco wspomagać pracę nad projektem badawczym i w rozmaity sposób wzbogacać przebieg poszczególnych rozmów. Podstawowym celem każdego wywiadu było nie tylko pozyskanie odpowiedzi na problemy zawarte w dyspozycjach badawczych, ale także poszukiwanie rozmaitych nowych wątków badanego problemu, do których nie sposób dotrzeć w pełni za pomocą standardowego kwestionariusza.

Ostatecznie przeprowadzono wywiady z 32 kobietami i 43 mężczyznami. Zdecydowaną większość rozmówców stanowiły osoby na stałe mieszkające w Lodzi (56 osób), pozostała część pochodziła z innych miejscowości województwa łódzkiego (7 osób to mieszkańcy aglomeracji łódzkiej, 10 osób pochodziło z innych miast województwa łódzkiego), a jedynie nieliczni rozmówcy opowiadali o Łodzi z perspektywy osób związanych z tym miastem jedynie w czasie podejmowanych studiów, a na stałe mieszkających w innych częściach kraju (2 osoby). Co ważne, osoby pochodzące spoza obszaru aglomeracji łódzkiej zamieszkiwały w wynajętych mieszkaniach już od pierwszego roku studiów, a część $\mathrm{z}$ nich dopuszczała także możliwość pozostania w mieście na dłużej. Łódź ze swoją bogatą ofertą edukacyjną (w mieście działa obecnie 6 państwowych uczelni wyższych i ponad 20 uczelni wyższych niepublicznych) stała się dla naszych rozmówców przestrzenią życia studenckiego, a zarazem podstawą organizacji ich

${ }^{4} \mathrm{~W}$ trakcie prowadzenia badań i opracowywania ich wyników Społeczna Wyższa Szkoła Przedsiębiorczości i Zarządzania (w tekście - SWSP) w Łodzi zmieniła nazwę na Społeczną Akademię Nauk.

${ }^{5} \mathrm{~W}$ tym miejscu należy zauważyć, iż ilościowe badania dotyczące wizerunku miasta Łodzi w opiniach studentów w ciągu ostatnich 10 lat przeprowadzane były już wielokrotnie przez specjalistów reprezentujących różne dyscypliny naukowe. Wyniki tego rodzaju badań, opierających się głównie na metodzie ankietowej znaleźć można w wielu publikacjach naukowych, $\mathrm{m}$. in. w pracach: K. Mrowińskiej, M. Wilk, P. Pawłowskiego, Wizerunek miasta-główny warunek oceny jego funkcjonowania, [w:] Rozwój miast i regionów w procesie integracji europejskiej, red. Z. Przygodzki, Łódź 2006, s. 121-140; J. Jakóbczyk-Gryszkiewicz, Łódź w opinii studentów geografii, [w:] Percepcja wspótczesnej przestrzeni miejskiej, red. M. Madurowicz, Warszawa 2007, s. 231-241; Marka dla Łodzi. Strategiczne budowanie wizerunku miasta, red. T. Domański, Łódź 2008; M. E. Sokołowicz, E. M. Boryczka, Marka Łodzi jako czynnik budujacy tożsamość Łódzkiego Obszaru Metropolitalnego, [w:] Łódzka metropolia. Problemy integracji społecznej i przestrzennej, red. A. Suliborski, Z. Przygodzki, Łódź 2010, s. 71-96. 
samodzielnego życia codziennego i rozwiązywania wielu osobistych problemów i dylematów.

Przyjmując, że doświadczenie świata lokalnego jest jednym z podstawowych doświadczeń społecznych człowieka, interesowało nas, czym jest i jak wygląda lokalne doświadczenie współczesnej Łodzi w opiniach osób młodych, reprezentujących dosyć spójne środowisko społeczne, czyli społeczność studentów. Zaciekawiła nas odpowiedź na pytanie, co myślą o mieście ludzie młodzi jako osoby zdobywające wyższe wykształcenie i potencjalnie związane z przyszłością tego miasta? Jak wyglądają ich osobiste relacje z Łodzią; jaki obraz Lodzi wydobyć można $\mathrm{z}$ ich opinii o tym mieście; na czym polega dzisiejsza wartość tego miasta i jak wygląda jego oferta dotycząca pracy i codziennej egzystencji na tle innych dużych polskich metropolii? Czy Łódź może być dla studentów miastem, w którym, jeśli nie teraz, to w najbliższej przyszłości, stworzą oni własne „miejsce na ziemi", odczuwane jako ojczyzna lokalna, tworzona w sposób w pełni świadomy i odpowiedzialny? Ciekawa wydaje się również kwestia namysłu nad „tożsamością" współczesnej Łodzi, która budowana jest na podstawie wiedzy o życiu ludzi w określonych relacjach przestrzennych, kulturowych i społecznych, a także w odwołaniu do materialnego i niematerialnego dziedzictwa kultury tego miasta. $\mathrm{Na}$ te i inne pytania badawcze spróbuję znaleźć odpowiedź w szczegółowej analizie zebranego materiału empirycznego.

Wyniki badań jakościowych prowadzonych techniką wywiadu swobodnego trudno jest przełożyć na ilościowy sposób raportowania, a zatem w analizie zebranego materiału postaram się zaprezentować i omówić najważniejsze wątki i kwestie najczęściej podejmowane przez rozmówców w kontekście niniejszych rozważań.

Tematem pojawiającym się na początku większości zebranych wywiadów były najważniejsze skojarzenia dotyczące Łodzi, przywoływane zarówno w nawiązaniu do historii miasta, jak i w odniesieniu do teraźniejszości. Najpowszechniejszym skojarzeniem wynikającym z historycznych losów miasta i zachowanego do dziś dziedzictwa architektonicznego Łodzi była przemysłowa tradycja miasta oraz jego wielokulturowy charakter. Rozmówcy wymieniali jako obrazy kojarzone z Łodzią pofabryczne budynki wykonane $\mathrm{z}$ charakterystycznej czerwonej cegły, kominy oraz piękne pałace fabrykantów, które wciąż podkreślają specyfikę i odrębność przestrzeni Łodzi w stosunku do innych polskich miast. Wspominali także synagogi, wielokulturowe cmentarze oraz tragiczną historię żydowskiego getta. Włókiennicza i wielokulturowa tradycja miasta oraz zachowane do dziś jej rozmaite ślady, głównie natury architektonicznej, postrzegane były przez rozmówców jako niezwykle ciekawe i godne uznania, choć jednocześnie wymagające szczególnej troski w kontekście współczesnego obrazu miasta. Skojarzenia związane z aktualnym wizerunkiem Łodzi nie były już bowiem tak pozytywne i pełne akceptacji. W zdecydowanej większości wypowiedzi pojawiała się niechęć wobec obrazu miasta zaniedbanego 
i zapomnianego przez kolejnych miejskich włodarzy. Dla ilustracji przytoczmy fragmenty wybranych wypowiedzi:

Z czym kojarzy mi się Łódź? Niestety z brudem. Z brudem, korkami i dziurami w ulicach, $\mathrm{z}$ nie chodzącą komunikacją miejską wtedy, kiedy potrzeba $[\ldots] \mathrm{z}$ brakiem dobrego gospodarza gdzieś tam na pewno, ponieważ wiele rzeczy wydaje mi się, że można by inaczej w Łodzi rozwiązać. Większy nacisk mógłby być zdecydowanie kładziony na odnowienie tych wszystkich kamienic, które w tym momencie się sypią... i które straszą i wyglądają obrzydliwie, a są naprawdę przepięknymi budynkami i szkoda jest ich, a niestety jak dłużej tak będą zagospodarowane, to niestety nic z nich nie zostanie... I Łódź nie będzie już miała w ogóle czym się pochwalić, bo tak naprawdę, na tę chwilę te wszystkie właśnie budynki, pozostałości, to jest jedyna rzecz, którą na tę chwileczkę Łódź mogłaby się chwalić (wywiad nr 16, studentka UŁ, kierunek pedagogika, Zgierz).

Łódź kojarzy mi się z biedą, z postępującym wyludnieniem, ze starymi ludźmi, z tłokiem w autobusach, brudem i z zaniedbaną, ale piękną dziewiętnastowieczną architekturą. I oczywiście z czasami wielkiej świetności przemysłu lekkiego. Z okresem wolnego rynku na ziemiach polskich, z filantropią fabrykantów. O, jeszcze z hipermarketami i przekrętami przy przetargach. I brakiem pracy, wciąż jesteśmy tanią siłą roboczą dla Warszawy (wywiad nr 71, student UŁ, kierunek ekonomia, Łódź).

W zgromadzonych materiałach charakterystyczne jest konfrontowanie dawnego obrazu miasta przemysłowego, dynamicznie się rozwijającego, wielokulturowego, przesyconego kolorem czerwonej cegły z aktualnym wizerunkiem miasta szarego, brudnego i biednego, pozbawionego życiowej energii oraz możliwości znalezienia dobrej pracy, a także obrazem miasta, które nie potrafi dostrzec szans dla swojego gospodarczego rozwoju. Jak mówią informatorzy:

Łódź kojarzy mi się z fabrykami, włókiennictwem, wielokulturowością: żyli tu razem Niemcy, Żydzi i Rosjanie. Teraz to z chińskimi budkami, kebabami i lumpeksami na każdej ulicy po kilka sztuk. No i z brudem, zasikanymi bramami i tragiczną komunikacją miejską (wywiad nr 10, studentka UŁ, kierunek geografia, Łódź).

Historia Łodzi kojarzy mi się z miastem fabryk włókienniczych, tętniącym życiem, miastem kamienic zaludnionych robotnikami, taką ziemią obiecaną, miastem nowych możliwości. A obecnie? No cóż, największe miasto środkowej Polski, jedno z największych w naszym kraju w ogóle, lecz pomimo tego nie potrafiące wykorzystać swojej szansy, centralnego położenia, stające się powoli miastem coraz biedniejszym i coraz bardziej szarym (wywiad 9, student UŁ, kierunek archeologia, Budy Wolskie).

W prowadzonych ze studentami rozmowach jednym z tematów wiodących była kwestia symbolicznych reprezentacji Łodzi oraz miejsc charakterystycznych dla przestrzeni tego miasta. W zebranych wypowiedziach zauważyć można było pewnego rodzaju kontynuację myślenia o fabrycznej historii miasta i jej związku

\footnotetext{
${ }^{6} \mathrm{~W}$ nawiasach, poza numerami zebranych wywiadów, pomieszczone zostały informacje dotyczące rozmówców, tj. płeć, reprezentowana uczelnia, studiowany kierunek oraz miejsce stałego zamieszkania lub pochodzenia.
} 
z jego aktualnym wizerunkiem. Jako jeden z najważniejszych symboli Łodzi rozmówcy wymieniali bowiem architekturę pofabryczną i pałace fabrykantów, a w szczególności Pałac Izraela Poznańskiego i Manufakturę, znaną jako centrum kulturalno-rozrywkowe zlokalizowane w zrewitalizowanym XIX-wiecznym kompleksie pofabrycznym przy ulicy Ogrodowej, a także Księży Młyn, czyli zespół pofabryczny Karola Scheiblera, obejmujący pałac, budynek fabryczny oraz obiekty towarzyszące, $\mathrm{m}$. in. osiedle domów robotniczych, budynek straży pożarnej i szpital. Manufaktura jako przestrzeń zrewitalizowana i pełniąca szereg ważnych funkcji społeczno-kulturowych pojawiła się w zdecydowanej większości wypowiedzi naszych rozmówców jako miejsce szczególnie cenione, odpowiednie do spędzania czasu wolnego i reprezentacyjne dla miasta. Studenci podkreślali, że:

Manufaktura jest ważnym miejscem w Łodzi. Z tego co wiem, to zachwycają się nią nawet turyści z zagranicy. Połączenie historycznej architektury z nowoczesnym designem i zastosowaniem. Takie adaptacje są raczej niespotykane (wywiad nr 6, student UŁ, kierunek finanse i rachunkowość, Łódź)

Manufaktura ma klimat i historię, byłam ostatnio w Muzeum Fabryki na mini wykładzie o rodzinie Poznańskich. Podoba mi się wygląd Manufaktury, że jest tam dużo ciekawych knajpek, każdy znajdzie coś dla siebie. [...] To dobre miejsce na spotkanie z przyjaciółmi czy znajomymi. [...] Manufaktura jest fajna, jak jest na przykład jakieś duże okienko w wykładach, jak jest kiepska pogoda, to można pójść się powygłupiać ze znajomymi. I jest dobra na zakupy, jak ktoś szuka prezentu albo czegoś fajnego do ubrania, czegokolwiek, tam wszystko można znaleźć (wywiad nr 30, studentka UŁ, kierunek etnologia, Łódź).

Manufaktura to taka bardzo kolorowa wizytówka Łodzi. Dzięki niej nareszcie Łódź nie kojarzy się tylko z brudem, zasikanymi bramami i dopalaczami. Bardzo mi się podoba architektura Manufaktury, zresztą jest to miejsce, do którego bardzo często przyjeżdżam - na zakupy czy do jakiejś fajnej restauracyjki coś zjeść (wywiad nr 56, studentka PŁ, kierunek wzornictwo, Łódź).

Symbolicznym miejscem dla przestrzeni Łodzi wciąż pozostaje również ulica Piotrkowska, określana jako jedna z najdłuższych ulic handlowych w miastach europejskich, która pełni funkcje reprezentacyjne, a także stanowi ścisłe centrum miasta. Jak wyznawali nasi informatorzy:

Charakterystyczna dla Łodzi jest ulica Piotrkowska, szczególnie wieczorem i nocą. To ona jest sercem Łodzi. [...] Obecnie zmienia się postrzeganie tego najdłuższego deptaka Europy, zaczyna się dostrzegać piękno tej ulicy, coś zaczyna się zmieniać w umysłach łodzian. Jestem na Pietrynie codziennie, tam pracuje moja mama, tamtędy wracam z zajęć, spotykam się ze znajomymi (wywiad nr 9, student UŁ, kierunek archeologia, Budy Wolskie).

Piotrkowska jest najbardziej według mnie reprezentatywną częścią Łodzi. Można tam zobaczyć jak ciekawie zagospodarowano stare kamienice, można odwiedzić restauracje, pochodzić po różnych sklepach, odwiedzić kina, na przykład kino Charlie. To takie typowe łódzkie miejsce, którego nie widziałem w innym mieście (wywiad nr 44, student PŁ, kierunek zarządzanie produkcją, Łódź). 
Ulica Piotrkowska od lat stanowiła najbardziej charakterystyczną ulicę Łodzi, wymienianą jako symbol tego miasta w większości przeprowadzonych badań dotyczących sposobu postrzegania Łodzi nie tylko przez studentów lokalnych uczelni, ale także przez mieszkańców miasta i turystów. Jako ciekawostkę można dodać, że ta najbardziej znana łódzka ulica zajęła ostatnio pierwsze miejsce w plebiscycie na symbol miasta Łodzi, przeprowadzonym przez portal Onet.pl (uzyskała 40\% głosów), a także, dzięki aktywności łódzkich internautów, wygrała prowadzone w Internecie głosowanie na wizytówkę Polski w Google Street View, serwisie umożliwiającym wirtualny spacer po różnych fragmentach miejskich przestrzeni, odwiedzanym przez miliony internautów na świecie. W tym ostatnim konkursie Piotrkowska rywalizowała m. in. ze Starym Rynkiem we Wrocławiu i Poznaniu, krakowskim Rynkiem Głównym oraz lubelskim i toruńskim Starym Miastem $^{7}$. Co więcej, można nawet powiedzieć, że przekonanie o symbolicznym dla Łodzi charakterze ulicy Piotrkowskiej stanowi rodzaj kulturowego stereotypu wpisanego w wizerunek tego miasta, obecnego także w świadomości mieszkańców innych części kraju.

W grupie miejsc znamiennych i ważnych dla Łodzi rozmówcy wymieniali również plac Wolności, Łódzką Szkołę Filmową, Księży Młyn, stację kolejową Radegast, ale także charakterystyczne dla Łodzi przestrzenie parkowe i leśne Park im. Poniatowskiego, Park na Zdrowiu, Park Julianowski, Park 3-go Maja, Park Śledzia oraz Las Łagiewnicki. Zadziwiający jest fakt, że opisom zaniedbanego obecnie miasta, głównie jego architektury, ulic i chodników, przeciwstawiane były wzmianki dotyczące piękna łódzkich parków, które, zdaniem rozmówców, zachwycają swoim krajobrazem i czystością, stwarzając w mieście swoistą oazę spokoju i estetycznego ładu. Dla ilustracji sposobu postrzegania łódzkich parków, przytoczmy znamienne wypowiedzi:

Jak dla mnie to parki należą do bardzo pozytywnych cech Łodzi. W Łodzi są bardzo ładne. Najbardziej lubię park Na Zdrowiu, ale uważam, że większość łódzkich parków jest w porządku. No i przede wszystkim Łagiewniki, są największym kompleksem przymiejskim leśnym. [...] ich duża liczba jest niewątpliwym plusem Łodzi, to się dla mnie liczy, bo bardzo lubię zieleń. Moim zdaniem Łódź ma bardzo duży potencjał w kwestii terenów zielonych (wywiad nr 66, student PŁ, kierunek inżynieria środowiska, Jeżów).

Bardzo lubię Arturówek. Już nie mogę się doczekać jak będę mogła jeździć rowerem do parku, brać ze sobą koc, coś do jedzenia i picia. Uwielbiam spędzać tam miło chwile z chłopakiem bardzo mnie to odpręża. Zawsze jak nadejdzie wiosna, to pierwsze co w wiosennych porządkach zostaje wyciągnięte to mój rower i rolki. Ja najbardziej lubię Łódź parkową, zieloną, pachnącą wiosną, w przeciwieństwie do tej pełnej szarych kamienic, brudnych ulic i zmęczonych ludzi (wywiad nr 56, studentka PŁ, kierunek wzornictwo, Łódź).

${ }^{7}$ http://lodz.gazeta.pl/lodz/1,35153,11207353,Piotrkowska_w_Google_Street_View_Musisz_to_zobaczyc_html, [18.04.2012]. 
Ponadto symbolami Łodzi studenci określali także cztery kultury wpisane w historię miasta, czyli polską, rosyjską, niemiecką i żydowską, których współistnienie w łódzkiej tradycji kulturowej jeszcze kilkanaście lat temu całkiem trafnie próbowano wykorzystać w budowaniu promocyjnego wizerunku miasta (Festiwal Dialogu Czterech Kultur). Wskazywali również na kojarzące się z Łodzią lokalne kluby piłkarskie (RTS Widzew i ŁKS), których zwolennicy prowadzą ze sobą nieustanną rywalizację, zauważalną także $\mathrm{w}$ przestrzeni miasta $\mathrm{w}$ postaci napisów na murach (często niecenzuralnych) i rozmaitych emblematów umieszczanych nie zawsze w przystosowanych do tego miejscach.

Z przeprowadzonych rozmów wynika również, że do znamiennych łódzkich wydarzeń kulturalnych zaliczyć trzeba organizowane w tym mieście do niedawna festiwale: Międzynarodowy Festiwal Sztuki Autorów Zdjęć Filmowych „Camerimage” oraz wspomniany wyżej Festiwal Dialogu Czterech Kultur, a także Paradę Wolności (pierwszy festiwal muzyki techno w Polsce), której organizacja w Łodzi została zawieszona w roku 2003 w czasie pełnienia funkcji Prezydenta Miasta przez Jerzego Kropiwnickiego. Wszystkie trzy wydarzenia wymieniane przez naszych rozmówców należą już - niestety - do przeszłości w kulturalnym kalendarzu miasta i, co najważniejsze, rozmówcy nie wymieniają w ich miejsce żadnych aktualnych łódzkich wydarzeń kulturalnych, może z jednym wyjątkiem, który pojawił się w wypowiedziach dosłownie kilku osób - Fashion Philosophy Fashion Week Poland, który określany był jako największe w Polsce wydarzenie poświęcone modzie. Zastanawiające jest, dlaczego w zebranych materiałach nie było nawet jednej wzmianki na temat odbywającego się $\mathrm{w}$ ostatnim czasie w Łodzi Międzynarodowego Festiwalu Designu (Łódź Design Festival), Forum Kina Europejskiego Cinergia czy rozmaitych festiwali teatralnych (Festiwal Sztuk Przyjemnych i Nieprzyjemnych, Festiwal Dotknij Teatru, Festiwal Kultury Chrześcijańskiej). Wynika z tego, że rozmówcy mówili nie tyle o projektach kulturalnych znanych z własnych doświadczeń, ale raczej o wydarzeniach szeroko omawianych w przekazach medialnych, które zdobyły rozgłos nie tylko ze względu na swą wartość artystyczną. Zarówno Camerimage, Festiwal Dialogu Czterech Kultur, jak i Parada Wolności wspominane były wielokrotnie w mediach w kontekście strat, jakie poniosło miasto w związku z zawieszeniem ich kolejnych edycji lub przeniesieniem ich organizacji do innych miast. Na podstawie zebranych wypowiedzi zauważyć można, że nasi rozmówcy posługiwali się głównie stereotypowymi opiniami na temat kulturalnego życia w Łodzi, jednocześnie informując o własnym znikomym uczestnictwie w aktualnych miejskich wydarzeniach kulturalnych.

Z drugiej strony jednak widać, jak wielką szansą na budowanie pozytywnego wizerunku miasta było odwoływanie się w odpowiednim czasie do filmowej (Camerimage) i wielokulturowej (Festiwal Dialogu Czterech Kultur) tradycji miasta, a także jak strategie reklamujące wspomniane wydarzenia spełniły swoją rolę w promocji Łodzi, na długo zapisując się w świadomości społecznej. Być może 
pojawiły się we właściwym dla rozwoju miasta momencie, trafiając na odpowiedni grunt społeczny i spełniając społeczne oczekiwania osób nieznużonych jeszcze niekonsekwentnymi działaniami władz miasta. W ocenie minionych wydarzeń kulturalnych Łodzi (festiwale, Parada) bardzo duże znaczenie ma bowiem zdecydowanie negatywny sposób postrzegania działalności władz miejskich, a szczególnie aktywności prezydenta Jerzego Kropiwnickiego. Co ciekawe, prezydent Kropiwnicki wciąż pojawia się jako osoba odpowiedzialna za obecny negatywny wizerunek miasta. Rozmówcy wielokrotnie podkreślali, że:

Osobliwością tego miasta są już od wielu lat jego władze, wybrane w demokratycznych wyborach, które nic nie robią dla tego miasta, oddając takie imprezy kulturalne jak Camerimage czy rezygnują z podjęcia się goszczenia meczu EURO 2012 (wywiad nr 9, student UŁ, kierunek archeologia, Budy Wolskie).

Mało się dzieje - prawie żadnych koncertów itp. (chociaż ostatnio coś tam się lekko ruszyło, ale to się okaże, co będzie dalej). Mieliśmy festiwale - nie ma kasy i festiwali już też nie. Mamy straszne władze miejskie, które nie robią nic dobrego dla ludzi. Komunikacja miejska - lepiej nie mówić. Drogi - tragedia. [...] Na Euro 2012 nawet kandydatury nie wysłano, a jakby stadion powstał, to też by był plus dla Łodzi, bo i kasa z mistrzostw samych i później obiekt do wykorzystania by już został na 100 lat (wywiad nr 6, student UŁ, kierunek finanse i rachunkowość, Łódź).

W gronie osób szczególnie kojarzonych z Łodzią były także postaci historyczne, takie jak Julian Tuwim, Artur Rubinstein, Władysław Reymont oraz łódzcy fabrykanci - Poznański, Grohman oraz Biedermann, z kręgu zaś współcześnie znanych ludzi, poza prezydentem Kropiwnickim, wymieniany był Marek Edelman, Roman Polański, Leszek Miller czy Marek Janiak.

Tematyka miejsc charakterystycznych dla przestrzeni miasta w wielu wypowiedziach uzupełniana była również opisami miejsc ulubionych na łódzkiej mapie i najlepiej rozpoznanych przez rozmówców. Studenci pochodzący z Łodzi całkiem naturalnie wymieniali przede wszystkim najbliższe okolice własnego miejsca zamieszkania, w których spędzali zazwyczaj dzieciństwo i lata młodości, doświadczając uroków codziennej egzystencji. W ich wypowiedziach pojawiały się opinie dotyczące niezwykłości czy też odrębnego od reszty miasta charakteru wybranych osiedli lub dzielnic:

Stoki nie uważają się za Łódź, Stoki to Stoki, Janów, Olechów - to też nie jest miasto, oni jeżdżą do Łodzi, czyli jeżdżą do centrum, tak? Radogoszcz uważa, że jest wsią... i tak dalej [...] chyba tylko ktoś mieszkający na Piotrkowskiej by powiedział, że naprawdę mieszka w Łodzi (wywiad nr 17, studentka UŁ, kierunek etnologia, Łódź).

Zdecydowanie najbardziej czuje się związany z Teofilowem, bo tutaj się wychowałem. Doceniam ten motyw lokalności. Nie twierdzę, że będę tu mieszkał całe życie, ale nawet jeśli wyjadę na krócej czy dłużej to zawsze chciałbym mieć możliwość powrotu do Łodzi. I tu chciałbym kiedyś wrócić na stałe, dokładnie na Teofilów. To chyba mimo wszystko moje miejsce na ziemi (wywiad nr 3, student UŁ, stosunki międzynarodowe, Łódź). 
Lubię Retkinię, tam jest bardziej kolorowo, jest więcej natury: pagórków, skwerów, drzew. Tam można spokojnie wyjść na spacer, pies ma się gdzie wybiegać, są place zabaw dla dzieci. Jest tam po prostu sympatycznie (wywiad nr 41, studentka UŁ, kierunek etnologia, Łódź).

W zebranym materiale odnaleźć można także wypowiedzi opisujące konkretne miejsca w przestrzeni miejskiej, ważne zarówno dla łodzian, jak i dla rozmówców pochodzących z innych miejscowości, znane z ich własnego doświadczenia i nasycone, w ich osobistym odczuciu, rozmaitymi znaczeniami społecznymi.

Moje ulubione miejsca to Palmiarnia łódzka i antykwariat „Silva Rerum”. Palmiarnia, bo jest tam bardzo ciepło i bardzo duża wilgotność. Szczerze mówiąc to nienawidzę zimy, więc kiedy tylko spada śnieg, chodzę tam regularnie, żeby trochę odreagować. Zresztą uwielbiam rośliny, a miejsce to jest atrakcyjne, ponieważ rośnie tam sporo egzotycznych okazów. Kolejną zaletą tego miejsca jest to, że jest tam cicho... A antykwariat? Obsługa jest w porządku i mają niedrogie książki. Ten antykwariat ma w sobie to coś. Już na wejściu czuć specyficzny i przyjemny dla mnie zapach starych zakurzonych książek (wywiad nr 66, student PŁ, kierunek inżynieria środowiska, Jeżów).

Moim ulubionym miejscem w Łodzi jest zdecydowanie murek koło CPN-u (plac Komuny Paryskiej, uwaga K.O-D), ale nie dlatego, że jestem amatorem picia piwa w miejscach publicznych. Dlatego, że wciąż spotykam tam ludzi, których znam jeszcze z liceum. Mogę z nimi porozmawiać, mogę ich zobaczyć. To jest taki punkt centralny w momencie, gdy umawiamy się na jakieś wspólne wyjście. Miejsce przecięcia się wielu życiorysów młodych ludzi. I przy okazji, co bardzo ważne przynajmniej dla mnie, że nie uświadczysz tam patologii. Nikt się z nikim nie bije, nie ma żadnych i niepotrzebnych spięć (wywiad nr 3, student UŁ, kierunek stosunki międzynarodowe, Łódź).

Moim ulubionym miejscem jest Park Śledzia. Kojarzy mi się ze spotkaniami towarzyskimi, gdy siadamy na trawie i całe letnie popołudnie przesiadujemy tam ze znajomymi. Zawsze jest tam dużo ludzi, można poznać kogoś nowego, porozmawiać z tymi starszymi panami grającymi w szachy lub karty. Często śmiejemy się, że na starość podtrzymamy tę tradycję i będziemy grać w szachy. Co jeszcze? Park kojarzy mi się z randkami. Tam zaprosiłem swoją pierwszą dziewczynę. Spacerowaliśmy, ona zrywała jakieś kwiatki. Tak więc same dobre wspomnienia (wywiad nr 39, student PŁ, kierunek budownictwo, Łódź).

Z analizy materiałów wynika, że sposób postrzegania Łodzi zdecydowanie zmieniał się, kiedy rozmówcy w swych wypowiedziach poruszali kwestie miejsc ulubionych i ważnych dla siebie w tym mieście, przybliżając jednocześnie własne doświadczenia społeczno-przestrzenne. Negatywny obraz miasta, wyrażany w ogólnych opiniach o Łodzi, zyskiwał wówczas bardziej łagodną postać, a przestrzeń miasta wydawała się skrywać wiele ciekawych zakątków. Jednakże w całym zebranym materiale empirycznym wzmianki dotyczące obszarów postrzeganych w sposób szczególny należały do nielicznych. Zdecydowanie częściej pojawiały się opisy dotyczące miasta jako całości - miasta zaniedbanego, brudnego, przesyconego ogólną atmosferą smutku i bezsilności. Niezwykle interesująca okazała się poruszana w rozmowach problematyka emocji i wrażeń zmysłowych związanych z indywidualnym odczuwaniem Łodzi. Zacznijmy może od przytoczenia kilku znamiennych wypowiedzi: 
Nie lubię Łodzi, bo jest szara i brzydka, jest dużo menelstwa, a policja jeździ tylko po Piotrkowskiej. [...] Czuje raczej niechęć, brak entuzjazmu. Po prostu miasto jest brzydkie, niebezpieczne, niby dużo firm, ale o pracę ciężko. Jest coraz gorzej (wywiad nr 6, student UŁ, finanse i rachunkowość, Łódź).

Źle się czuję w Łodzi. Miasto jest nudne. Nie ma tutaj ciekawych miejsc, cała reszta jest w opłakanym stanie. Jedyny plus to parki, poza tym kojarzy mi się z brudem i psimi kupami na chodnikach w centrum miasta. [...] Najgorzej jest na wiosnę jak się ociepla. Śmierdzi na każdym kroku (wywiad nr 5, student UM, kierunek medycyna, Łódź).

Moje emocje związane z Łodzią to złość, różne rodzaje złości, czasami aż do momentu frustracji, bo już nie raz stałam na przystanku i krzyczałam... I taki trochę, taki gdzieś smutek, bo jest mi zwyczajnie szkoda jak patrzę na to miasto (wywiad nr 16, studentka UŁ, kierunek pedagogika, Zgierz).

Wobec Łodzi czuję przykrość i bezsilność by cokolwiek tu zmienić, ale nie są to uczucia nadrzędne, bo mimo wszystko widzę jakąś nadzieję, czuję moc i potencjał wśród przyjaciół. [...] Czuję się łodzianinem, bo urodziłem się w tym mieście. [...] tutaj tak naprawdę zawiązałem pierwsze poważne przyjaźnie, trwające do dzisiaj (wywiad nr 3, student UŁ, kierunek stosunki międzynarodowe, Łódź).

Większość rozmówców próbowała również w swoich wypowiedziach dokończyć frazę, rozpoczynającą się od słów: „łódzki, czyli...”. Ta prośba o skonstruowanie dość krótkiej, kilkuwyrazowej opinii o mieście przyniosła w zdecydowanej większości rozmów efekt pesymistyczny. Rozmówcy, starając się dopełnić sformułowanie ,łódzki, czyli...”, mówili:

...szary, nijaki, smutny (wywiad nr 9, student UŁ, kierunek archeologia, Budy Wolskie).

...smętny, szary, bez nadziei, zaniedbany, betonowy (wywiad nr 7, student PŁ, kierunek transport, Łódź).

...brudny. Nie wiem, zakompleksiony względem innych miast. Wiesz jest taki trend po prostu, ostatnio ludzie wychwalają Łódź, jakie to jest zajebiste miasto, ale tak naprawdę nie ma wielu rzeczy, którymi możemy się pochwalić. Myślę, że w gruncie rzeczy wszyscy łodzianie zazdroszczą takim mieszkańcom Wrocławia albo Warszawy, Poznania chociażby. To są miasta, które dużo lepiej prosperują po prostu (wywiad nr 4, student UŁ, kierunek turystyka i rekreacja, Łódź).

...łódzki czyli ludzki, ponieważ żyje tu duża ilość biednych ludzi i dosięgają ich zwykłe, proste rzeczy i zdarzenia (wywiad nr 39, student PŁ, kierunek budownictwo, Łódź).

...biedny, patologiczny, wiem, że to nie są najlepsze określenia, ale jakim przymiotnikiem opisałbyś miasto, w którym dwóch podpitych facetów w dresach ucina ci palec butelką, gdy wychodzisz przed klub na papierosa. Takie historie się tu zdarzają. Wiesz o czym mówię, o dzieciach w beczkach, o tych wszystkich kretynach, za przeproszeniem, którzy tylko czyhają w bramach, żeby cię okraść albo pobić pałkami i kamieniami. Jest tu niestety masę prostactwa. Ale może zbyt surowo na to patrzę. I przyszło mi na myśl dopełnienie tego przymiotnika... wiesz, łódzki czyli mój (wywiad nr 3, student UŁ, kierunek stosunki międzynarodowe, Łódź). 
...łódzki czyli melancholijny, szary, powolny, brudny, przemęczony, a jednocześnie z intrygującą przeszłością, z ogromnym bagażem doświadczeń. Łódź kojarzy mi się ze zgarbionym starcem, którego ktoś cały czas kopie w tyłek (wywiad nr 44, student PŁ, kierunek zarządzanie produkcją, Łódź).

Sporadycznie spotkać można było jednak także innego rodzaju dopełnienia:

Łódzki, czyli... imprezowy. No w końcu to miasto żyje nocą trochę bardziej niż większość miast i miasteczek w tym kraju. Jest gdzie pójść, można wybierać i przebierać w klubach. Życie nocne naprawdę tu kwietnie niemal codziennie (wywiad nr 15, studentka UM, kierunek lekarsko-dentystyczny, Włocławek).

Wizerunek Łodzi jako miasta źle zarządzanego, zaniedbanego i bez perspektyw na dynamiczny rozwój konfrontowany był powszechnie w wypowiedziach studentów z obrazami innych polskich miast. Rozmówcy podkreślali, że:

Łódź jest na szarym końcu. [...] Widziałam Wrocław, widziałam Poznań, Warszawę, Gdańsk - tak naprawdę parę fajnych, ciekawych miast - i tam wiadomo, że w momencie jak człowiek zbliża się do centrum, to widać, że ktoś zarządza tym miastem, że jest odpowiednio spożytkowany kapitał, że jest po prostu dobry gospodarz. Te miasta się non stop rozwijają, ładowane są pieniądze w zabytki, ładowane są pieniądze w promocję ewentualnie i to się czuje na pierwszy rzut, jak się tam człowiek pojawia. Zresztą jest kupa turystów. Ciągnie tam turystów, wszyscy są zadowoleni, mają ochotę tam wrócić. [...] a niestety jak człowiek wraca do tej Łodzi i zaczyna na nią patrzeć, to tak naprawdę się zastanawia, że tutaj zwyczajnie nic nie ma (wywiad nr 16, studentka UŁ, kierunek pedagogika, Zgierz).

Łódź przede wszystkim jest duża - mieszka tu bardzo dużo osób. Dochody na mieszkańca są niskie, przez co miasto staje się trochę wylęgarnią patologii. W porównaniu do innych miast wyróżnia się tym, że skala jest większa. Kraków i Warszawa są większe - Kraków zwycięża architekturą, która jest moim zdaniem ładniejsza niż w Łodzi. Warszawa zaś jest w sytuacji jak Luksemburg, jest siedliskiem urzędników i przede wszystkim miejscem reprezentacyjnym Polski. Łódź jest skrzywdzona, bo jest blisko Warszawy, tam ludzie mają więcej perspektyw. Obecnie sytuacja wygląda tak, że ktoś, kto mógłby robić coś w Łodzi, jedzie do Warszawy. Ciężko identyfikować się z tym miastem... Jak dla mnie ciężko się z nim identyfikować, bo jak mam się utożsamiać z czymś, co nie dało mi w gruncie rzeczy nic dobrego (wywiad nr 66, student PŁ, kierunek inżynieria środowiska, Jeżów).

W zebranych materiałach odnaleźć można jednak także wypowiedzi ilustrujące pewnego rodzaju przywiązanie do Łodzi jako własnej przestrzeni życiowej. Dotyczy to głównie osób mieszkających w tym mieście od dzieciństwa. Rozmówcy, niezależnie od dostrzegania rozmaitych niedoskonałości w wizerunku miasta, dostrzegają także jego specyficzny charakter i pełną uroku atmosferę, kreując w swych wypowiedziach nieco sentymentalne obrazy miasta i jego najbardziej reprezentacyjnych przestrzeni. Na szczególną uwagę zasługują przejawy odpowiedzialnego podejścia do budowania pozytywnego wizerunku Łodzi jako społeczno-kulturowej całości. Zacytujmy fragmenty wybranych wypowiedzi: 
Każde miasto różni się czymś od pozostałych miast, nie ma przecież dwóch takich samych miast. [...] Dla mnie Łódź wyróżnia się właśnie między innymi klimatem. Tu jest tak swojsko, no ale każdy czuje to inaczej i każdy ma prawo mieć swoje zdanie. [...] Lubię tu wracać, jak gdzieś wyjadę, to moje miasto, tu się wychowałem, więc jestem do niego w pewien sposób przywiązany i mam do niego spory sentyment, takiego czegoś nie okazuje się na co dzień, ale to się wie, to się czuje (wywiad nr 14, student UŁ, kierunek informatyka, Łódź).

Porównując Łódź z innymi miastami można powiedzieć, że Łódź jest szara, ale ta szarość ma wiele odcieni - od głębokiej czerni aż po biel. W przeciwieństwie do innych miast to przechadzając się po Łodzi, po jej różnych uliczkach możemy wpaść w taki melancholijny nastrój, którego nie odczujemy nigdzie indziej. Ta specyficzna fabrykancka historia naszego miasta daje się tu we znaki. I nawet mnie osobiście wprawiają w zachwyt te łódzkie miejsca. Do moich ulubionych należy kompleks fabrykancki Poznańskiego, którego elementy nadal są widoczne, mimo, że jest tam teraz Manufaktura. Lubię też kompleks Scheiblera przekształcony obecnie w lofty, a także opuszczoną w tym momencie fabrykę na ulicy Tymienieckiego - tam między Tymienieckiego a Milionową. No i Księży Młyn [...] Kiedy odwiedzam te miejsca to czuję taką melancholię... (wywiad nr 44, student PŁ, kierunek zarządzanie produkcją, Łódź).

Się człowiek czuje odpowiedzialny trochę za Łódź. Odpowiedzialny za bronienie jej przed napastliwymi komentarzami ludzi z innych miast... zawsze się robi przykro (wywiad nr 17, studentka UŁ, kierunek etnologia, Łódź).

Jestem łodzianinem, urodziłem się tutaj, mieszkam tutaj, uczę się tutaj i pracuję. Nie wiem jak to dalej się potoczy. Jednak aby być takim łodzianinem z krwi i kości to dla mnie trzeba odczuwać ten specyficzny klimat miasta, trzeba się wczuć w atmosferę jaka tu panuje. Nawet ci którzy nie spędzili tu swojego dzieciństwa, a potrafią się zagłębić w Łódź to śmiało mogą powiedzieć, że są łodzianami. Miasto ma coś w sobie, co przyciąga mimo swojej szarości i przygnębienia. I naprawdę, gdybym miał kiedyś gdzieś indziej mieszkać, to na pewno nie zostawiłbym tego miasta ot tak. $\mathrm{Na}$ pewno bym tu wracał dosyć często (wywiad nr 44, student PŁ, kierunek zarządzanie produkcją, Łódź).

Pod warstwą powszechnie powielanych negatywnych opinii o mieście, wypowiadanych $\mathrm{w}$ zebranym materiale, niejako $\mathrm{w}$ pierwszej kolejności dostrzec można zatem również przejawy utożsamiania się z Łodzią. Nie są to wprawdzie wypowiedzi pełne zachwytu nad urokiem i potencjałem miasta, ale uwidocznia się w nich zwyczajne, ludzkie przywiązanie do zamieszkiwanej i doświadczanej na co dzień przestrzeni, określanej mianem własnej, wobec której rozmówcy odczuwają jednak pewnego rodzaju moralne zobowiązanie.

Niezależnie od dominujących negatywnych opinii o mieście studenci potrafili także wskazać obiekty czy miejsca, które poleciliby osobom odwiedzającym Łódź, jako interesujące i warte bliższego poznania. Pośród takich miejsc pojawiła się oczywiście łódzka Manufaktura wraz z Pałacem Poznańskiego, Księży Młyn, ulica Piotrkowska, ale także łódzkie muzea, z Muzeum Sztuki na czele, a także łódzki Ogród Botaniczny czy Aquapark „Fala”. Rozmówcy bardzo chętnie podejmowali również w swych wypowiedziach kwestie dotyczące tego, co w Łodzi 
powinno ulec zdecydowanej poprawie; mówili o przyszłości tego miasta w perspektywie najbliższych 10-15 lat. Zaprezentujmy zatem fragmenty zebranych materiałów:

Łódź powinna przestać być traktowana jak sypialnia Warszawy i miasto celowo umartwiane, w którym ludzie piją wódkę, bawią się i śpią, a pracują i żyją w Warszawie czy mniejszych okolicznych miastach. Chciałbym, żeby kiedyś Łódź znalazła hmm... to zabrzmi dziwnie, ale swoje miejsce, wiesz o co mi chodzi, żeby określiła swoją tożsamość, obrała jakiś konkretny kierunek. Podobał mi się pomysł miasta festiwalowego, tak jak było kiedyś, ale oczywiście zostało to zabite przez władze. Więc może to jest dobry pomysł, żeby zmiany zacząc od zmiany ludzi rządzących (wywiad nr 3, student UŁ, kierunek stosunki międzynarodowe, Łódź).

Wolałabym, żeby rzeczywiście doprowadzili do tego, że spokojnie ktoś mógłby tu przyjechać na fajny koncert i na jakieś inne wydarzenia, przedsięwzięcia związane tak naprawdę tutaj z Łodzią, i żeby było ich jak najwięcej. Daj Panie Boże, i żeby można było rzeczywiście wtedy gdzieś wyjść, można było komuś coś porządnego pokazać (wywiad nr 16, studentka UŁ, kierunek pedagogika, Zgierz).

Powinno się o to miasto bardziej zadbać. Niektóre miejsca wyglądają niczym z jakiegoś horroru. $Z$ tego co mi wiadomo bywa tu też ciężko z pracą. To też stanowczo powinno się zmienić. No ale przez najbliższe lata miejmy nadzieję, że coś ulegnie zmianie i za tych kilkanaście lat już nikt nie będzie miał podstaw, aby narzekać, że jest brudno, brzydko i pracy nie ma i strach wyjść na ulicę, że nie ma gdzie pójść z dzieckiem na spacer. Ktoś się tym może wreszcie zajmie. Powinno się też coś zrobić z drogami w centrum, niektóre wyglądają tak, że nie da się nimi w ogóle przejechać (wywiad nr 15, studentka UM, kierunek lekarsko-dentystyczny, Włocławek).

Myślę, że ktoś w końcu musi zadbać o to miasto, bo teraz miejscami to po prostu jest syf i oczy pękają. Powinno się coś zrobić z wieloma budynkami w centrum, odremontować czy coś w tym stylu. Czasem odnosi się wrażenie, że świetnie kręciłoby się tu film wojenny, taka po prostu ruina... Aż strach patrzeć czasem, czekać tylko, aż to runie. Chciałbym przede wszystkim, aby ktoś zrobił z tym porządek. A tak poza tym, to miło by było, gdyby Łódź stała się miastem dla poważnych zagranicznych inwestorów, ale tak pełną gębą. Tak, aby młodzi ludzie mieli w całym tym biznesie jakąś godziwą pracę na ludzkich warunkach. Chciałbym widzieć jakiś progres, nie zastój, albo co gorsza regres, jak teraz. Niech miasto się rozwija, nie stoi w miejscu, a kto wie, może za jakiś czas, chociaż i tak pewnie za milion lat, dorównamy, albo i przewyższymy stolicę. Mam taką nadzieję, wszystko w naszych rękach (wywiad nr 14, student UŁ, kierunek informatyka, Łódź).

Rekapitulując, należy zauważyć że w całości zebranego materiału dominuje dość ogólna wiedza o mieście, o jego zabytkach, infrastrukturze, poczynaniach władz i nowych możliwościach rozwoju, która ma charakter trwałej obiegowej opinii, stereotypowo powtarzanej na różnych poziomach komunikacji społecznej, utrwalonej w świadomości zarówno łodzian, jak i mieszkańców innych polskich miast. Ciekawe w tej kwestii wyniki przyniosły wywiady na temat różnego rodzaju anegdot, dowcipów czy też plotek o życiu w mieście. W odpowiedziach pojawiły się głównie wzmianki o popularnych swego czasu w przekazie medialnym informacjach dotyczących afer i zbrodni, przede wszystkim nadużyć w łódzkim 
pogotowiu ratunkowym i dokonanego przez łodzianina zabójstwa dzieci, których zwłoki przechowywał w beczkach. Trwałość i niezmienność tego negatywnego wizerunku Łodzi, wynikającego z szeregu niefortunnych wydarzeń sprzed kilku czy też kilkunastu lat wydaje się być również bardzo niepokojąca. Świadczy to bowiem o braku nowych impulsów do zmiany wizerunku miasta w świadomości jego użytkowników oraz o potrzebie nowych, odpowiednio wypromowanych przedsięwzięć, służących przełamaniu serii negatywnie postrzeganych zdarzeń, jakie miały miejsce w Łodzi w ostatnich latach. Chodzi tu zarówno o medialnie nagłośnione afery i nieszczęśliwe zdarzenia, jak i decyzje urzędników oceniane jako niewłaściwe, które doprowadziły do zniknięcia z łódzkiej przestrzeni ważnych dla promocyjnego wizerunku miasta wydarzeń kulturalnych.

$\mathrm{Na}$ podstawie zebranych w toku badań materiałów zrekonstruować można zatem bardzo znamienną opowieść o Łodzi, w której pojawia się obraz miasta W stanie zawieszenia pomiędzy przeszłością, związaną z intensywnym rozwojem przemysłu włókienniczego, a przyszłością, która wydaje się być pozbawiona konkretnego kierunku rozwoju. W wypowiedziach dotyczących znanych studentom narracji o Łodzi dziwi brak znajomości jakichkolwiek przekazów z zakresu folkloru miejskiego, co świadczy przede wszystkim o braku gruntownej wiedzy o tradycji miasta, a także o potrzebie stworzenia spójnego związku pomiędzy postrzeganiem i odczuwaniem miasta a tożsamością jego mieszkańców. Z sentymentem opowiada się jedynie barwne historie o wydarzeniach z obszaru własnego osiedla, rzadziej dzielnicy, traktując przestrzeń całego miasta jako pozbawioną znaczeń ważnych dla wspólnoty łodzian. Być może istnieje potrzeba działań na rzecz większego uświadomienia folklorystycznej tradycji miasta (choćby specyfiki folkloru robotniczego), a także na temat charakteru i obszaru działalności jego obecnych folklorotwórczych środowisk społecznych. Związek człowieka z określoną przestrzenią, jej krajobrazem, tradycją i aktualnymi problemami wyrażał się bowiem od zawsze w rozmaitych przekazach o charakterze folklorystycznym, których podstawę stanowił przede wszystkim wspólny, grupowy światopogląd ${ }^{8}$.

Zmiana kulturowego wizerunku miasta wymaga również, być może, większej aktywności oddolnej, wpływającej na wytworzenie i utrzymywanie się w żywym obiegu społecznym pozytywnych opowieści o mieście, wyrastających zarówno z tradycji miasta, jak i subiektywnego postrzegania przestrzeni i potencjału społeczno-kulturowego współczesnej Łodzi. Ciekawy przykład stanowić mogą poświęcone tematyce Łodzi liczne fotoblogi zamieszczane na stronach internetowych, prowadzone przez zainteresowanych miastem młodych łodzian ${ }^{9}$. W tego

\footnotetext{
${ }^{8}$ Por. P. Bogatyriew, R. Jakobson, Folklor jako swoista forma twórczości, [w:] P. Bogatyriew, Semiotyka kultury ludowej, Wstęp, wybór i oprac. M. R. Mayenowa, Warszawa 1979, s. 305-319.

${ }^{9} \mathrm{~K}$. Orszulak-Dudkowska, MojaŁódź.pl - społeczna promocja miasta w komunikacji internetowej, [w:] Komunikowanie się w społeczeństwie wiedzy XXI wieku, red. N. Majchrzak, A. Zduniak, seria „Edukacja XXI wieku”, t. 25, WSB, Poznań 2011, s. 327-341.
} 
typu wirtualnych przekazach Łódź pojawia się jako miasto niezwykłe, wymagające uważnego i skupionego na detalach oglądu. Zauważyć można, że:

Autorzy fotoblogów w sposób spontaniczny obserwują miasto, a jednocześnie utrwalają i pogłębiają pamięć o swych ulubionych, a także ciekawych i ważnych miejscach miasta, odgrzebują zapomniane historie, uaktualniają je i starają się je rozwijać w przekazie kolektywnym. Poprzez swoją nieoficjalną aktywność społeczną fotoblogerzy starają się także kreować obraz Łodzi zdecydowanie przeciwstawny wobec negatywnego stereotypu miasta zaniedbanego i biednego, wskazując jednocześnie na ukryty w Łodzi i jej mieszkańcach potencjał rozmaitych możliwości, głównie o charakterze artystycznym ${ }^{10}$.

Takie nieformalne osobiste zaangażowanie mieszkańców Łodzi w tworzenie wizerunku miasta na potrzeby szerszej zbiorowości, czynione w sposób oddolny, a zarazem autentyczny, wydaje się być nieocenione dla miasta i jego przyszłego rozwoju. Ma ono silny związek z problemem rekonstrukcji miejskiej tożsamości, z poszukiwaniem łódzkiego genius loci, które stanowić powinno podstawę nowoczesnego myślenia o mieście, ale także stać się częścią jednostkowych tożsamości jego mieszkańców. Tymczasem z zebranych materiałów empirycznych niezwykle trudno wydobyć elementy wskazujące na silny związek łódzkich studentów z tradycją i kulturą tego miasta; trudno zauważyć także przejawy ich odpowiedzialnego obywatelskiego myślenia o rozwoju Łodzi i jej przyszłości. Warto zauważyć, że w zebranych materiałach dosłownie kilka osób deklarowało swe zaangażowanie w działalność społeczną na obszarze miasta, w tym aktywność w studenckim radiu ,Żak".

W kontekście przeprowadzonych analiz warto przypomnieć, że związek ludzi z ich lokalnym światem może być tworzony również w sposób odgórny i świadomy, w oparciu o zaprojektowane rozmaite akcje społeczne i kampanie promujące dziedzictwo regionu czy miasta ${ }^{11}$. Być może zatem, poza budowaniem oddolnej obywatelskiej aktywności, w przypadku Łodzi potrzeba także szeregu profesjonalnych odgórnych działań, mających na celu sztuczne nieco odtwarzanie

${ }^{10}$ Ibidem, s. 339-340.

${ }^{11}$ Doskonałym przekładem tego rodzaju działań, zauważonych skądinąd przez specjalistyczne środowisko, była opracowana na rzecz miasta kampania informacyjna promująca Łódź pod hasłem „Czy wiesz, że...”, przygotowana przez Łukasza Zbieranowskiego i Macieja Lebiedowicza, tworzących grupę „Fajne Chłopaki Zakłady Przemysłu Graficznego i Internetowego”. Kampania prowadzona była w okresie letnim 2011 r. w formie citylightów i billboardów rozmieszczonych w Łodzi i regionie oraz w warszawskim metrze. W kampanii pojawiły się informacje o dziesięciu osiągnięciach łódzkich firm, które miały świadczyć o kreatywności i innowacyjności łódzkiego przemysłu, $\mathrm{m}$. in. informowano o tym, że: w Łodzi wymyślono pierwszą w Polsce społecznościową wytwórnię muzyczną, zaprojektowano pierwszą w Polsce kamizelkę igło-, nożo- i kuloodporną, opracowano technologie najmniejszych cząsteczek nanosrebra, tworzone jest oprogramowanie dla lotniczych gigantów czy też wymyślono program do sterowania komputerem za pomocą mrugnięć powieki. Zob.http://www.marketingowiec.pl/.../czy-wiesz-ze-w-lodzi-startuje-nowa-kampania-informacyjna-miasta, [11.04.2012]. 
zapomnianej tradycji miasta, w tym miejskiego folkloru i opowieści o barwnym życiu miasta i życiu w mieście na różnych etapach jego rozwoju. $Z$ tego względu niezwykle ważne powinny być nie tylko działania lokalnych władz, opracowanie interesujących materiałów promujących miasto, ale także odpowiednia aktywność choćby zawodowych przewodników po Łodzi, opowiadających swoim zainteresowanym słuchaczom różnego typu historie, nie zawsze oficjalne (związane z tradycją fabrykancką, włókienniczą czy filmową miasta, zabytkami i obiektami architektury, ulicami, zaułkami i miejscami, a także samymi mieszkańcami miasta i jego bywalcami), przekładające się na tworzenie w powszechnym obiegu pozytywnego stereotypowego obrazu miasta. Przejawy tego rodzaju działalności, otwartej również na dialog z lokalną społecznością, wykazują obecne już w mieście firmy, na przykład Grupa Fabricum, której aktywność, w tym zapoznawanie $\mathrm{z}$ historią, tradycją i atmosferą miasta, opiera się w dużej mierze na pracy łódzkich studentów ${ }^{12}$. Działalność tego rodzaju organizacji powinna się jednak zdecydowanie upowszechnić i, co więcej, przekładać się nie tylko na usługi dla turystów odwiedzających miasto, ale również na lokalną wiedzę o mieście, jaką dysponują jego mieszkańcy i użytkownicy.

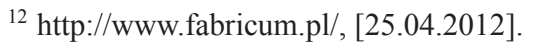

